\title{
PELATIHAN PENGOLAHAN ES PUTER DAN ES KRIM PADA KELOMPOK BANK SAMPAH BINTANG MANGROVE, GUNUNG ANYAR SURABAYA
}

\author{
Jariyah $^{1)^{*}}$, Sri Djajati ${ }^{2)}$, Anugerah Dany Priyanto ${ }^{3)}$ \\ ${ }^{1,2,3)}$ Program Studi Teknologi Pangan, Fakultas Teknik, Universitas Pembangunan Nasional \\ "Veteran” Jawa Timur. email: jariyah.tp@upnjatim.ac.id
}

\begin{abstract}
ABSTRAK
Pemanfaatan buah mangrove sebagai bahan dasar minuman belum dilakukan secara optimal, untuk itu, perlu dikembangkan lebih lanjut menjadi produk minuman yang mempunyai kandungan nutrisi yang tinggi. Implementasi dari penelitian tersebut yaitu pada kegiatan pengabdian masyarakat pada kelompok Bank Sampah Bintang Mangrove (BSBM). Ketrampilan yang diberikan yaitu pembuatan minuman beku berupa es puter dan es krim dengan bahan dasar buah mangrove. Metode yang digunakan dalam memfasilitasi peningkatan ketrampilan kelompok BSBM dengan memberikan pelatihan berupa metode ceramah, praktik dan pendampingan. Metode ceramah dengan memberikan teori dasar dalam pengolahan buah mangrove menjadi es puter dan es krim, sehingga mempunyai nilai tambah baik dari segi rasa maupun nutrisi dari minuman tersebut. Metode praktik yaitu memberikan pelatihan yang ditekankan pada kemampuan kelompok BSBM dalam membuat minuman yang mempunyai rasa dan kandungan nutrisi tinggi, memiliki fungsi terhadap kesehatan. Pelatihan ini lebih mengedepankan partisipasi aktif kelompok BSBM serta memberikan pendampingan untuk keberlanjutan kegiatan usaha dan pemasaran. Luaran dari kegiatan ini adalah dihasilkan produk minuman yang mempunyai kandungan nutrisi dan produk inovatif, sehingga dapat membantu menambah pendapatan kelompok BSBM.
\end{abstract}

Kata kunci: Es Puter, Es Krim, Buah Mangrove, Gunung Anyar, Pengabdian Masyarakat

\section{ABSTRACT}

Utilizarion of mangrove fruit as a main ingredient for drinks has not been carried out optimally, therefore, it is necessary to develop into beverage products within higly nutrition value. Implementation of research result by community service to Bank Sampah Bintang Mangrove (BSBM) group (BSBM). The given skills are production of frozen drinks into es puter and ice cream with mangrove fruit as the main ingredient. The method used in facilitating the improvement of the skills from BSBM group were conducted by training of lecture method, practice and mentoring. The lecture method provided a basic theory of processing mangrove fruit into es puter and ice cream, so that it has added value in terms of both taste and nutrition from the drink. The practical method was to provide training that emphasizes the ability of the BSBM group in making drinks that have high taste and nutritional value, which have a function for health. This training emphasizes the active participation of the BSBM group and provides assistance for the sustainability of business and marketing activities. The output of this activity is to produce beverage products that have nutritional value and innovative product, in order to increase their income from BSBM group.

Keywords: Es Puter, Ice Cream, Mangrove Fruit, Gunung Anyar, Community Service

\section{PENDAHULUAN}

Kawasan kampung nelayan Gunung

Anyar Tambak, Surabaya, terdapat kelompok

Bank Sampah Bintang Mangrove (BSBM), yang diketuai oleh ibu Kusniyati, yang berdiri sejak tahun 2012. Pada kelompok tersebut pernah diberi pelatihan tahun 2019 tentang proses pengolahan buah mangrove untuk diolah menjadi biskuit, dan cara pemasaran secara online, namun produk olahannya masih perlu ditambahkan, sehingga produk yang dipasarkan lebih banyak dan variatif. Adapun produk yang akan dikembangkan pada program penerapan 
hasil penelitian bagi masyarakat (PIHAT) yaitu produk olahan minuman buah magrove.

Produk minuman buah mangrove selama ini hanya berupa sirup, sehingga hanya dapat dikonsumsi oleh kalangan tertentu.

Menurut kelompok BSBM pembuatan sirup dari buah mangrove (bogem) tersebut telah dibuat oleh masyarakat untuk pengobatan dan diproduksi jika ada kunjungan dari pemda Surabaya dan hanya dapat dikonsumsi oleh orang dewasa, dan itupun hanya orang tertentu sehingga tidak bisa berkembang dengan baik. Hal ini disebabkan : (1) pengetahuan yang minim dalam melakukan inovasi produk minuman, (2) keterbatasan peralatan yang dimiliki, dan mereka tidak mengerti formula yang tepat untuk membuat produk minuman buah mangrove, (3) ukuran perbandingan antara bubur buah, gula, dan air yang digunakan, sehingga sirup kualitasnya kurang baik, karena mengalami fermentasi. Dengan demikian yang mereka baru diketahui oleh kelompok BSBM yaitu membuat sirup dari buah mangrove jenis pedada, itupun hanya diketahui oleh kelompok tertentu saja, sehingga buah mangrove yang ada tidak termanfaatkan secara optimal.

Oleh karena itu melalui program PIHAT ini diharapkan masyarakat dapat mengembangkan produk minuman dari buah mangrove, supaya dapat meningkatkan ketrampilan, pengetahuan dan penghasilan kelompok BSBM dalam membuat aneka produk olahan buah mangrove. Hal ini sangat penting mengingat buah mangrove baik untuk kesehatan, seperti misalnya buah mangrove jenis pedada (Sonneratia caseolaris) dan lindur (Bruguiera ghymnorhiza), serta jenis buah mangrove lainnya. Kandungan antioksidan yang terdapat pada buah mangrove dapat mencegah adanya radikal bebas yang sangat berbahaya dalam tubuh (Bandaranayake, 2002), sedangkan kandungan serat pangan pada buah mangrove bersifat mengenyangkan dan mampu menurunkan kadar gula darah [1, 2] dan kolesterol [3, 4], sehingga sangat baik untuk kesehatan. Buah mangrove juga kaya provitamin A, vitamin B5, vitamin B2, vitamin C (Manulu, 2011) dan mengandung beberapa jenis mineral yang sangat baik untuk fungsi pertahanan tubuh.

Berdasarkan potensi gizi yang terkandung pada buah mangrove akan sangat bermanfaat jika ditambahkan atau sebagai bahan dasar dalam pembuatan produk olahan pangan, dengan demikian akan membantu meningkatkan gizi yang lebih baik bagi masyarakat luas, dan mendorong usaha-usaha diversifikasi pangan. Selain itu keinginan masyarakat selalu berkembang terutama berkaitan produk olahan minuman. Oleh karena itu perlu kiranya dikembangkan beraneka ragam produk minuman yang berbasis buah mangrove, dengan tujuan untuk memanfaatkan potensi sumber daya alam yang ada secara optimal, selain itu dapat menambah variasi jenis minuman olahan sehat berbahan dasar buah mangrove. 
Beberapa jenis produk olahan yang dapat dibuat dengan bahan dasar buah mangrove yaitu membuat sirup, selai dan dodol, dari buah mangrove jenis pedada (Sonneratia caseolaris), bolu dan puding api-api (Avicennia marina).

Berdasarkan hasil wawancara kelompok BSBM, maka pada prorgam PIHAT ini akan dilakukan pelatihan dan pendampingan pengolahan buah mangrove menjadi produk minuman yaitu es puter dan es krim dari buah mangrove jenis bogem atau pedada (Sonneratia caseolaris), yang diharapkan dapat menjadi produk minuman unggulan di desa setempat.

\section{METODE PELAKSANAAN KEGIATAN}

\section{Metode Pendekatan}

Metode yang digunakan dalam memfasilitasi peningkatan ketrampilan kelompok BSBM dalam pengolahan minuman yang memanfaatkan sumber daya alam lokal buah mangrove di desa Gunung Anyar adalah dengan mengadakan pelatihan dengan metode pelatihannya adalah :

a. Metode Ceramah yaitu pemberian teori dasar dalam pengolahan produk minuman seperti es puter dan es krim dengan memberikan tambahan bahan dasar buah mangrove, sehingga mempunyai nilai baik dari segi jenis, rasa, maupun nutrisi dari produk minuman tersebut.

b. Metode Praktik yaitu memberikan pelatihan yang ditekankan pada kemampuan ketrampilan masyarakat dalam mengolah produk minuman yang lebih kreatif dan inovatif, sehingga mempunyai rasa khas buah mangrove, dengan kandungan nutrisi yang bermanfaat bagi kesehatan, dan mempunyai nilai tambah (added value) dengan metode praktek secara langsung. Pelatihan ini lebih mengedepankan partisipasi aktif peserta.

c. Metode pendampingan untuk berkelanjutan kegiatan usaha dan pemasaran hasil.

\section{HASIL DAN PEMBAHASAN}

Tempat pelatihan yaitu balai pertemuan anggota BSBM. Sebelum dilakukan praktik pembuatan produk es puter dan es krim, maka mitra (kelompok BSBM) diberi penjelasan tentang teori tentang manfaat buah mangrove bagi kesehatan yang dapat dilihat pada Gambar 1. Penjelasan mengenai pembuatan es puter dan es krim seperti yang terlihat pada juga dilakukan agar dapat memberikan gambaran saat praktik berlangsung. Bahan-bahan yang digunakan saat pelatihan meliputi buah mangrove, CMC, sirup buah.

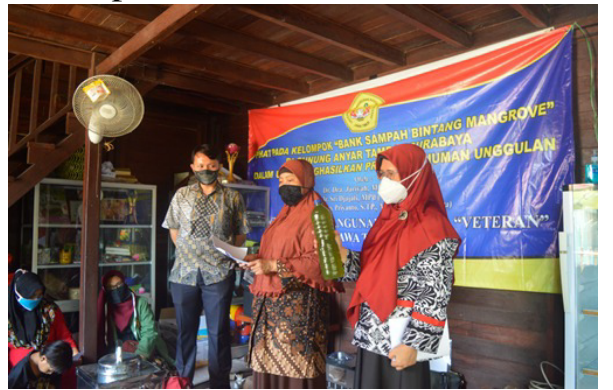

Gambar 1: Pelatihan kepada BSBM

Pelatihan di awali dengan berkoordinasi dengan mitra untuk pelaksanaan kegiatan. Sebelum pelaksanaan kegiatan dilakukan 
sosialisasi pengetahuan tentang pentingnya buah mangrove tehadap kesehatan, tentang es puter dan es krim. Kemudian dilanjutkan praktek membuatan produk minuman dari buah mangrove yaitu es puter dan es krim. Pelatihan es puter dilakukan menggunakan alat pendingin manual dan es krim menggunakan mesin es krim maker listrik yang dapat dilhat pada Gambar 2 dan Gambar 3.

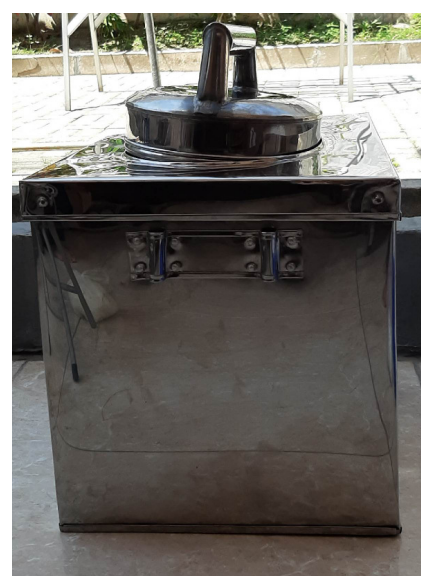

Gambar 2: Alat Pembuat Es Puter Manual

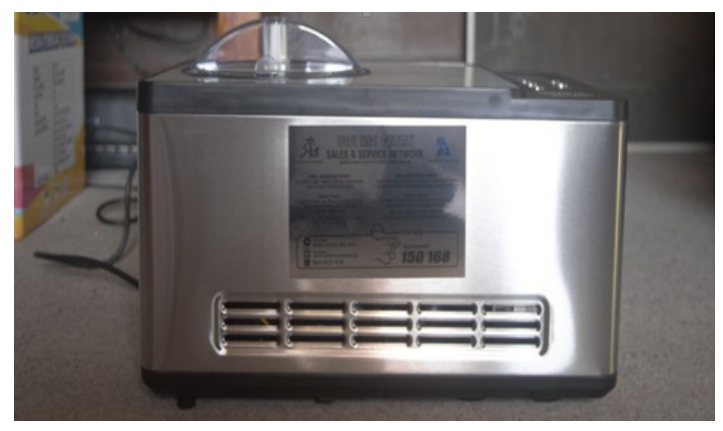

Gambar 3: Alat Pembuat Es Puter Manual

Produk es puter dan es krim ini sangat cocok untuk diproduksi anggota BSBM untuk menambah penghasilan mereka, karena prosesnya cukup sederhana. Hasil produk es puter dan es krim dari buah mangrove disajikan pada Gambar 4. Dari kedua produk yang dipraktekan pada saat pelatihan dengan anggota kelompok BSBM mendapatkan tanggapan yang sangat positif, semua peserta dapat mengikuti dengan seksama dan ikut mempraktikan dalam proses pembuatan produk es puter dan es krim.

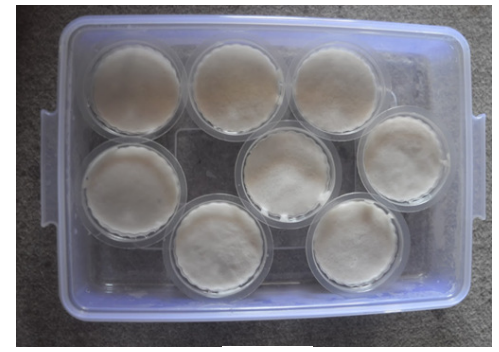

(a)

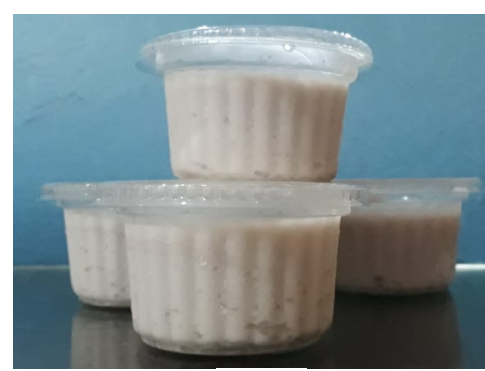

(b)

Gambar 4: (a) es puter, (b) es krim

Pada prinsipnya perbedaan pada bahan tambahan yang digunakan. Jika pada es krim ada tambahan susu sedangkan pada es puter tanpa ada tambahan susu, sehingga hasil akhirnya hamper sama. Berdasarkan hasil pelatihan menunjukkan bahwa dari data kuisioner yang diberikan kepada 15 orang peserta sebelum berlangsungnya acara dapat dilihat pada Tabel 1. Sebanyak $80 \%$ ibu/anggota BSBM tidak mengetahui perbedaan es puter dan es krim. Selain itu, sebesar 93\% kelompok BSBM tidak mengetahui bahan, alat, maupun cara pembuatan es puter dan es krim biasa ataupun dari olahan buah mangrove. Hal ini 
berkorelasi positif dengan kurangnya pengetahuan maupun informasi terkait produk olahan buah mangrove yang dikenal dengan sirup bogem, ditunjukkan dengan angka prosentase ketidaktahuan kelompok BSMB sebesar 93\%. Menurut kelompok BSMB, pelatihan yang diberikan dapat memberikan manfaat dianataranya yaitu menambah wawasan ilmu yang dapat menunjang pengembangan ide berwirausaha.

Pengetahuan masyarakat BSBM masih banyak yang belum mengetahui seputar es puter dan es krim dapat disebabkan karena wilayah mereka yang dekat dengan pesisir. Hal tersebut dimungkinkan karena situasi dan kondisi mereka yang kesehariannya hanya berprofesi sebagai penangkap ikan, walaupun disekitar mereka terdapat banyak hasil tanaman mangrove, akan tetapi mereka masih belum bisa memanfaatkan buah tersebut. Oleh karena itu, pentingnya transfer ilmu dan teknologi mengenai pengolahan hasil buah mangrove khususnya pada kali ini yaitu buah bogem yang banyak terdapat pada kawasan tersebut.

Tabel 1. Hasil Tanggapan Peserta pada Pelatihan Es Puter dan Es Krim Buah Mangrove

\begin{tabular}{|l|r|r|}
\hline \multicolumn{1}{|c|}{ Pertanyaan } & \multicolumn{2}{c|}{ Jawaban Peserta } \\
\cline { 2 - 3 } & \multicolumn{1}{c|}{ Ya } & \multicolumn{1}{c|}{ Tidak } \\
\hline Apakah ibu/anggota BSMB tahu produk es puter? & 60 & 40 \\
\hline Apakah ibu/anggota BSMB tahu produk es krim? & 47 & 53 \\
\hline Apakah ibu/anggota BSMB tahu perbedaan es puter dan es krim? & 20 & 80 \\
\hline Apakah ibu/anggota BSMB tahu cara membuat es puter? & 7 & 93 \\
\hline Apakah ibu/anggota BSMB tahu cara membuat es krim? & 7 & 93 \\
\hline Apakah ibu/anggota BSMB tahu alat membuat es puter? & 7 & 93 \\
\hline Apakah ibu/anggota BSMB tahu alat membuat es krim? & 7 & 93 \\
\hline Apakah ibu/anggota BSMB tahu bahan membuat es puter? & 7 & 93 \\
\hline Apakah ibu/anggota BSMB tahu cara membuat es puter dari buah mangrove? & 7 & 93 \\
\hline Apakah ibu/anggota BSMB tahu cara membuat es krim dari buah mangrove? & 7 & 93 \\
\hline $\begin{array}{l}\text { Apakah ibu/anggota BSBM sudah memanfaatkan buah mangrove untuk produk } \\
\text { minuman (sirup bogem)? }\end{array}$ & 7 & 93 \\
\hline Bagaimana cara membuat sirup bogem? & 7 & 93 \\
\hline
\end{tabular}

Beberapa pendapat mitra tentang kegiatan PIHAT yaitu menambah pengetahuan, menambah ide jualan, menambah ilmu, ada produk cara berjualan, menambah wawasan dan ilmu, senang ada pengalaman baru, ada produk baru untuk membuat es krim, sangat senang dapat ilmu tambahan buat usaha, menambah wawasan, menambah pengalaman, bermanfaat karena menambah wawasan masyarakat, kegiatan sangat positif dan sangat bermanfaat, senang karena bisa menambah pengalaman, dan menambah ilmu. Harapannya program selanjutnya perlu adanya pengembangan produk diversifikasi dari buah mangrove agar dapat menjadikan masyarakat BSBM 
menjadi masyarakat yang mandiri khususnya perkumpulan ibu-ibu, sehingga dapat membantu menambah penghasilan dari para suami yang kesehariannya berpenghasilan dari nelayan. mangrove.

SARAN
Perlu adanya program dengan
keberlanjutan secara kontinyu, sehingga
menjadi masyarakat menjadi mandiri dalam
berwirausaha dan memanfaatkan potensi
hasil pesisir secara maksimal.

\section{SARAN}

Perlu adanya program dengan

\section{KESIMPULAN}

Kegiatan PIHAT sangat bermanfaat, yang ditunjukkan dengan $93 \%$ mitra belum mengetahui proses dan bahan pembuatan es krim dari buah mangrove. Kelompok BSBM setelah mengikuti program PIHAT ini bertambah pengetahuan mengenai pemanfaatan buah mangrove, sehingga tergerak untuk berwirausaha khususnya produk minuman berbahan baku buah
\end{abstract}

hasil pesisir secara maksimal.

\section{UCAPAN TERIMAKASIH}

Program ini sepenuhnya didanai oleh

LPPM, UPN “Veteran” Jawa Timur.

\section{REFERENSI}

[1] Rahmatullah, M. , Md. N. K. Azam, S. Pramanik, Sania, S.Rahman, and R. Jahan. 2012. Antihyperglycemic activity Evaluation of Rhizomes of Curcuma zedoaria (Christm.) Roscoe and Fruits of Sonneratia caseolaris (L.)Engl. International Journal of PharmTech Research. 4(1):125-129.

[2] Jariyah, Widjanarko, S.B. , Estiasih, T. and Yunianta. 2014. Hypoglycemic effect of Pedada (Sonneratia caseolaris) Fruit Flour (PFF). in alloxan-induced diabetic rats. International Journal of PharmTech Research. Vol.7, No.1, pp 31-40.

[3] Ahmed, R., S.J. Moushumi, H. Ahmed, M. Ali, W. M. Haq, R.Jahan, and M. Rahmatullah. 2010. Serum Glucose and Lipid Profiles in Rats Following Administration of Sonneratia Caseolaris (L.) Engl. (Sonneratiaceae) Leaf Powder in Diet. Advances in Natural and Applied Sciences,4(2):171-173.

[4] Jariyah, Azkiyah, L., Widjanarko, S.B., Estiasih, T., Yuwono, S.S and Yunianta. 2013. Hypocholesterolemic Effect of Pedada (Sonneratia caseolaris) Fruit Flour in Wistar Rats. International Journal of Pharm Tech Research. vol.5, No.4, pp.1619-1627. 